\title{
Assessment of Toilet's Indoor Air Quality in Relation to Asthmatic People
}

\author{
Ismail Abdul Rahman ${ }^{1}$, Jouvan Chandra Pratama Putra ${ }^{1} \&$ Ade Asmi ${ }^{2}$ \\ ${ }^{1}$ Department of Construction and Architecture, Faculty of Civil and Environmental Engineering, Universiti Tun \\ Hussein Onn Malaysia, Malaysia. \\ ${ }^{2}$ Civil Engineering Department, Bakrie University, Jakarta, Indonesia \\ Correspondence: Jouvan Chandra Pratama Putra, Department of Construction and Architecture, Faculty of Civil \\ and Environmental Engineering, Universiti Tun Hussein Onn Malaysia, Malaysia. E-mail: \\ jouvanchandra@gmail.com
}

Received: June 17, 2014 Accepted: June 19, $2014 \quad$ Online Published: September 27, 2014

doi:10.5539/mas.v8n5p289 URL: http://dx.doi.org/10.5539/mas.v8n5p289

\begin{abstract}
This paper presents an assessment on toilet's indoor air quality on asthmatic people. The assessment was carried out by measuring temperature, relative humidity, air velocity and $\mathrm{SO}_{2}$ in the 4 selected toilets which are naturally ventilated. The measurements used two equipments that are Yes Plus LGA meter and Anemometer. It was done in early morning and break hours for 10 minutes within three (3) days consecutively. This study found that $\mathrm{SO}_{2}$ concentration in toilet 1 exceeded the threshold limit value of $\mathrm{SO}_{2}$ for 10 minutes exposure which means this toilet potentially trigger asthmatic symptom for those asthmatic people who frequently used this toilet. High concentration of $\mathrm{SO}_{2}$ was due to inadequacy of air velocity in this toilet. Inadequacy of air velocity means less ventilation and thus, increased the humidity which can stimulate the growth of fungi/mold in the toilet that affects asthmatic people.
\end{abstract}

Keywords: asthma, indoor air quality, $\mathrm{so}_{2}$, toilet

\section{Introduction}

Indoor Air Quality (IAQ) is a terminology of air quality within and around buildings which pertinent with health and comfort of indoor occupant (Muhamad-darus et al., 2011; Murdoch \& Lloyd, 2010). The duration of time that people spent indoor and the risk to health posed by indoor air are the most issue that encourage researchers to conduct the study on indoor air (Frontczak \& Wargocki, 2011; Lee, 1997; Massey et al., 2009). In addition, several findings of IAQ studies from previous researchers indicated that coarse particulate matter $\left(\mathrm{PM}_{10}\right)$ which is less than 10 micrometers in diameter (Brunekreef \& Forsberg, 2005; Donaldson et al., 2000; Karakatsani et al., 2012; Zhang, 2005), fine particulate matter $\left(\mathrm{PM}_{2.5}\right)$ which is less than 2.5 micrometers in diameter (Brunekreef \& Forsberg, 2005; Karakatsani et al., 2012) and Sulfur Dioxide $\left(\mathrm{SO}_{2}\right)$ (Awbi, 1991; Guo, 2012; Luttinger \& Wilson, 2003; Restrepo, 2012; Tseng et al., 2012) in particular concentration could lead adverse effect for human inhalation such as asthmatic symptoms. However, the exposure of $\mathrm{SO}_{2}$ on human inhalation for asthmatic people in a concise time at particular concentration gives more significant effect to trigger the asthmatic symptoms as compared to $\mathrm{PM}_{10}$ and $\mathrm{PM}_{2.5}$ (World Health Organization, 1987).

Asthma is a heterogeneous disorder of the conducting airways involving chronic inflammation, declining function and tissue remodeling (Murdoch \& Lloyd, 2010). For asthmatic individuals, the inflammation causes wheezing, breathlessness, chest tightness and cough particularly at night and/or early morning (Bousquet et al., 2000). There are various researches on the effect of $\mathrm{SO}_{2}$ exposure to asthmatic people. Koren (1995) had exposed asthmatic people within 20 minutes of $\mathrm{SO}_{2}$ at $0.25 \mathrm{ppm}$ and found it affect to the bronchosconstriction function which finally lead to asthmatic symptom. In other situation, a laboratory experiment was conducted which involves 7 asthmatic people exposed to $0.5 \mathrm{ppm}$ of $\mathrm{SO}_{2}$ for 10 minutes and resulted to 3 people having wheezing and breathlessness (Sheppard et al., 1980). Furthermore, Balmes et al., (1987) had carried out a study on the effect of exposure to a humidified air for 5 minutes and $\mathrm{SO}_{2}$ in the range of $0.5-1 \mathrm{ppm}$ for 1,3 and 5 minutes on 2 females and 6 males of non-smoking asthmatic adult. They found that bronchoconstriction function increase the Spesific Airway Resistance (SRaw) above baseline with respect to the exposure time and 
concentration. Additionally, the other asthmatic triggers are smoke and humidity (Al-anzi \& Salman, 2011). Smoke is a mixture of smoke from the burning end of a cigarette, pipe or cigar and it exhaled by the smoker that is often found in homes, toilets and car where smoking is allowed. Besides, humidity can affect to the growth of mold and commonly found in the toilet, kitchen and the basement (Al-anzi \& Salman, 2011)

Based on the findings of previous studies which had been described above, it can be concluded that the exposure of $\mathrm{SO}_{2}$ in concise time is the main problem that could have effect on human inhalation. Subsequently, toilet in university is one of public facilities which frequently used either by staff or student in concise time. Thus, it motivates to assess its IAQ level in order to compare with the Threshold Limit Value (TLV).

\section{Method}

\section{A. Site Description}

This study was conducted on 4 selected toilets at Faculty of Civil and Environmental Engineering of Universiti Tun Hussein Onn Malaysia. The selected toilets (2 for gents and 2 for women) are naturally ventilated through opening of windows. Table 1 describes the characteristics of selected toilets.

Table 1. Characteristics of the selected toilets

\begin{tabular}{|c|c|c|c|c|c|c|c|c|c|}
\hline \multirow{3}{*}{ Toilet Number } & \multirow{3}{*}{$\begin{array}{l}\text { Toilet } \\
\text { Type }\end{array}$} & \multicolumn{6}{|c|}{$\begin{array}{c}\text { Number of Users During Measurement } \\
\text { (person) }\end{array}$} & \multirow{3}{*}{$\operatorname{Area}\left(\mathrm{m}^{2}\right)$} & \multirow{3}{*}{ Height (m) } \\
\hline & & \multicolumn{3}{|c|}{ Morning } & \multicolumn{3}{|c|}{ Noon Time } & & \\
\hline & & 1 & 2 & 3 & 1 & 2 & 3 & & \\
\hline 1 & Male & 6 & 4 & 2 & 4 & 2 & 1 & 10.12 & 2.8 \\
\hline 2 & Female & 4 & 3 & 2 & 4 & 2 & 3 & 10.12 & 2.8 \\
\hline 3 & Male & 1 & 4 & 1 & 1 & 5 & 3 & 10.12 & 2.8 \\
\hline 4 & Female & 3 & 5 & 1 & 1 & 2 & 3 & 10.12 & 2.8 \\
\hline
\end{tabular}

\section{B. Sample Collection and Analysis}

The measurements were conducted twice a day (in early morning and noon during break hours) for 10 minutes within 3 consecutive days. The measured parameters are air temperature, relative humidity and $\mathrm{SO}_{2}$ concentration which are measured by using Yes Plus LGA Meter and air velocity by using Anemometer. These equipments were placed vertically at a height of $1.2 \mathrm{~m}$ from the floor. During the measurement periods, the selected toilets function as usual with several users as in table 1. All the data gathered are analysed using descriptive statistical approach which includes mean, maximum and minimum values calculated using Microsoft Excel and presented into graph and bar chart.

\section{Results and Discussion}

The parameters of IAQ considered in this study are temperature, relative humidity, air velocity and $\mathrm{SO}_{2}$ concentration. The measured values of all the parameters and the analysis on the data are presented in this section

\subsection{Temperature and Relative Humidity}

The temperature and humidity are measured during 10 minutes duration in 3 days continuously in all the 4 toilets involved. The average values of temperature are presented as in figures 1 and 2 while relative humidity is presented as in figures 3 and 4 . Figure 1 shows the highest recorded temperature in the morning is $30{ }^{\circ} \mathrm{C}$ in the toilet 1 or toilet 2 at $2^{\text {nd }}$ day of and also in the toilet 1 , toilet 2 , or toilet 4 at $3^{\text {rd }}$ day of the measurement. For the lowest recorded temperature is $29^{\circ} \mathrm{C}$ at $1^{\text {st }}$ day of the morning measurement in toilet 1 , toilet 2 , toilet 3 and toilet 4. Subsequently, for temperatures at noon time, the highest recorded value is $31{ }^{\circ} \mathrm{C}$ at the toilet 4 at $2^{\text {nd }}$ day of noon time measurement and at the toilet 2 at $3^{\text {rd }}$ day of the measurement. For the lowest recorded temperature at noon time is $28.5^{\circ} \mathrm{C}$ which is at the toilet 1 at $1^{\text {st }}$ day of the measurement. 


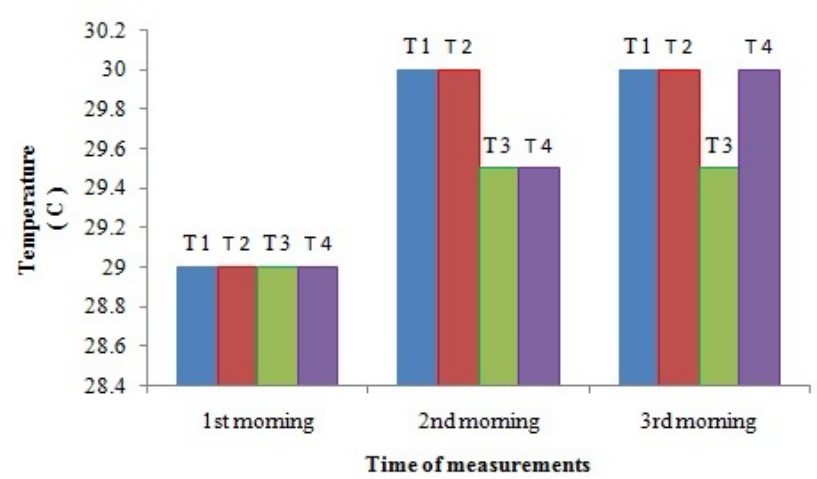

Figure 1. Measured morning temperature (toilet)

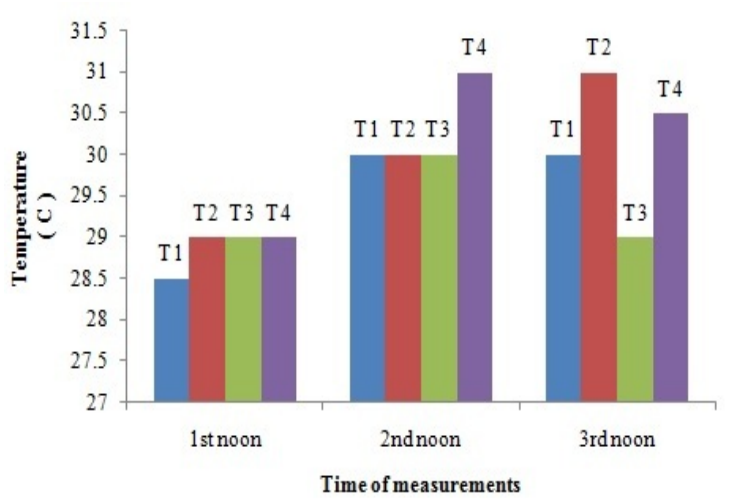

Figure 2. Measured noon temperature (toilet)

For the morning measurement as in figure 3, the highest average relative humidity measured is at $1^{\text {st }}$ day of toilet 1 or toilet 2 with the value of $94.5 \%$. For the lowest case, it was achieved at the $3^{\text {rd }}$ day with the value of $82.5 \%$ in toilet 4 . For the noon measurement as in figure 4 , the highest value is at the $1^{\text {st }}$ day with the value of $91.5 \%$ for toilet 1 and for the lowest is at $3^{\text {rd }}$ day with the value of $74.5 \%$ for toilet 2 .

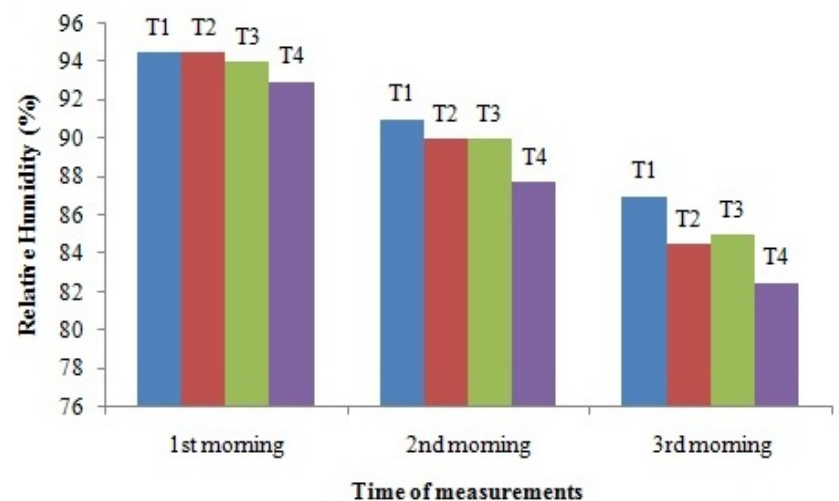

Figure 3. Measured morning relative humidity (toilet)

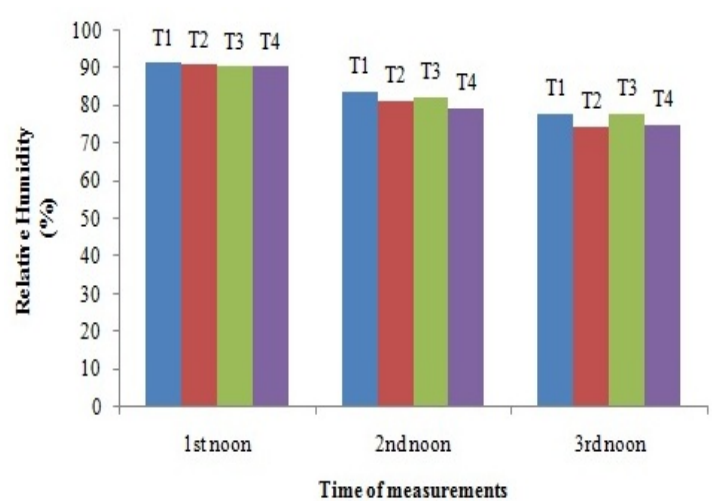

Figure 4. Measured noon relative humidity (toilet)

Al-anzi and Salman (2011) had stated that indoor humidity is one of the factors that contributes to asthmatic symptoms to asthmatic people. Since most of the toilets are experiencing high humidity thus this will trigger asthmatic symptoms for those asthmatic people who had frequently used this toilet.

\subsection{Ventilation Rate}

The air velocity was also measured for 10 minutes duration in all the 4 toilets in the morning and at noon time within 3 days period. The measured values are tabulated as in table 2.

Table 2. Measured Air Velocity in the Toilets

\begin{tabular}{|c|c|c|c|c|c|c|}
\hline \multirow{3}{*}{ Toilet } & \multicolumn{6}{|c|}{ Time of Measurement } \\
\hline & \multicolumn{3}{|c|}{ Morning } & \multicolumn{3}{|c|}{ Noon Time } \\
\hline & Day 1 & Day 2 & Day 3 & Day 1 & Day 2 & Day 3 \\
\hline 1 & $0.091 \mathrm{~m} / \mathrm{s}$ & $0.069 \mathrm{~m} / \mathrm{s}$ & $0.051 \mathrm{~m} / \mathrm{s}$ & $0.09 \mathrm{~m} / \mathrm{s}$ & $0.2 \mathrm{~m} / \mathrm{s}$ & $0.09 \mathrm{~m} / \mathrm{s}$ \\
\hline 2 & $0.132 \mathrm{~m} / \mathrm{s}$ & $0.099 \mathrm{~m} / \mathrm{s}$ & $0.065 \mathrm{~m} / \mathrm{s}$ & $0.11 \mathrm{~m} / \mathrm{s}$ & $0.16 \mathrm{~m} / \mathrm{s}$ & $0.09 \mathrm{~m} / \mathrm{s}$ \\
\hline 3 & $0.122 \mathrm{~m} / \mathrm{s}$ & $0.103 \mathrm{~m} / \mathrm{s}$ & $0.083 \mathrm{~m} / \mathrm{s}$ & $0.08 \mathrm{~m} / \mathrm{s}$ & $0.14 \mathrm{~m} / \mathrm{s}$ & $0.26 \mathrm{~m} / \mathrm{s}$ \\
\hline 4 & $0.091 \mathrm{~m} / \mathrm{s}$ & $0.098 \mathrm{~m} / \mathrm{s}$ & $0.105 \mathrm{~m} / \mathrm{s}$ & $0.1 \mathrm{~m} / \mathrm{s}$ & $0.19 \mathrm{~m} / \mathrm{s}$ & $0.05 \mathrm{~m} / \mathrm{s}$ \\
\hline
\end{tabular}

For morning measurement, the table shows that the highest air velocity is at toilet 2 with the value of $0.132 \mathrm{~m} / \mathrm{s}$ 
on the $1^{\text {st }}$ day of the measurement and for the lowest value is in toilet 1 with $0.051 \mathrm{~m} / \mathrm{s}$ on the $3^{\text {rd }}$ day of the measurement. For noon situation, the highest value is in toilet 3 with $0.26 \mathrm{~m} / \mathrm{s}$ on the $3^{\text {rd }}$ day and the lowest value is $0.05 \mathrm{~m} / \mathrm{s}$ in toilet 4 also on the $3^{\text {rd }}$ day of the measurement. These air velocity values are used to calculate airflow and thus, to determine the ventilation rate experienced by all the toilets. The airflow is calculated using the following formula:

$$
\begin{aligned}
& Q=V \times A \\
& \text { Where: } \quad \begin{array}{l}
Q=\text { Airflow }\left(\mathrm{m}^{3} / \mathrm{s}\right) \\
\mathrm{V}=\text { Air Velocity }(\mathrm{m} / \mathrm{s}) \\
\mathrm{A}=\text { Area }\left(\mathrm{m}^{2}\right)
\end{array}
\end{aligned}
$$

The calculated airflows of the toilets are presented as in figures 5 and 6 . For monring condition in figure 5 , the highest calculated airflow is at toilet 2 with the value of $1.337 \mathrm{~m}^{3} / \mathrm{s}$ on the $1^{\text {st }}$ day of measurement and the lowest is at toilet 1 on the $3^{\text {rd }}$ day of measurement with the value of $0.463 \mathrm{~m}^{3} / \mathrm{s}$. For noon time session, the highest of airflow is at toilet 1 with the value of $1.97 \mathrm{~m}^{3} / \mathrm{s}$ on the $2^{\text {nd }}$ day of measurement and the lowest is $0.05 \mathrm{~m}^{3} / \mathrm{s}$ at toilet 4 on the $3^{\text {rd }}$ day of measurement.

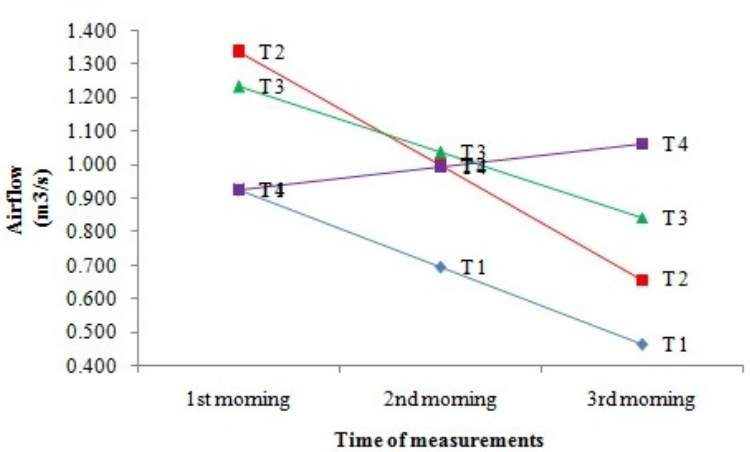

Figure 5. Calculated morning airflow

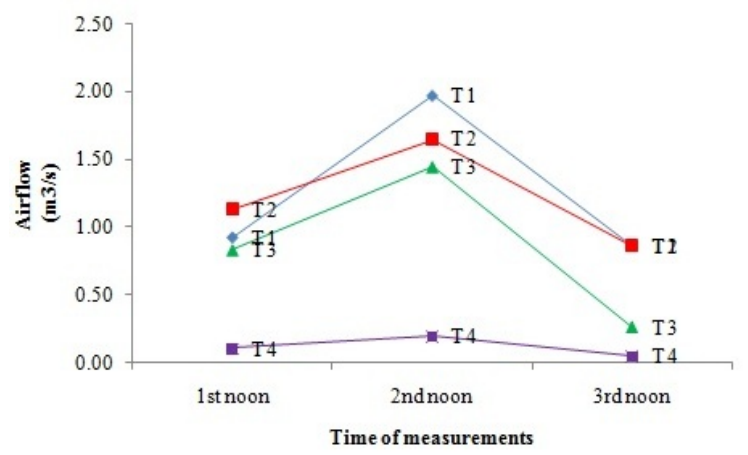

Figure 6. Calculated noon airflow

Subsequently, the flow rate is converted into ventilation rate to determine the adequacy of indoor air distributed for comparing with CIBSE standard, where the minimum ventilation rate for toilet is $629 \mathrm{1} / \mathrm{s} / \mathrm{p}$ (CIBSE, 2001). The ventilation rate is calculated using the following equation:

$$
V_{r}=Q / \text { person }
$$

Where:

$$
\begin{aligned}
& \mathrm{Vr}=\text { Ventilation rate }(\mathrm{l} / \mathrm{s} / \mathrm{p}) \\
& \mathrm{Q}=\text { Airflow }(1 / \mathrm{s})
\end{aligned}
$$

The calculated ventilation rates for all 4 toilets in morning and at noon time are presented as in figures 7 and 8 .

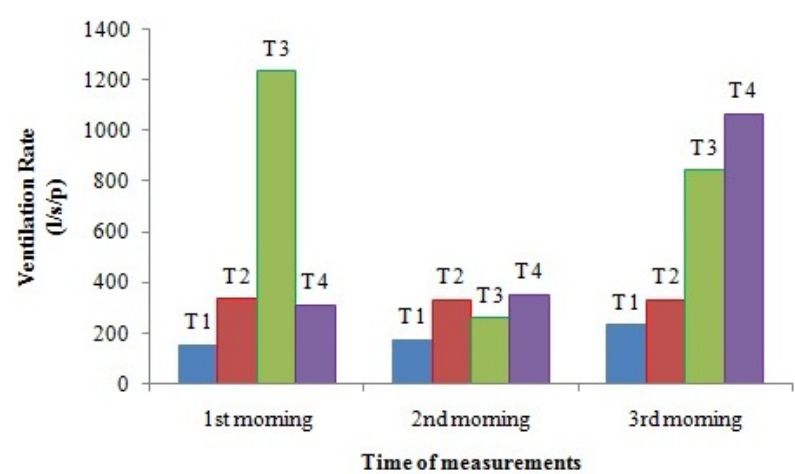

Figure 7. Morning ventilation rate

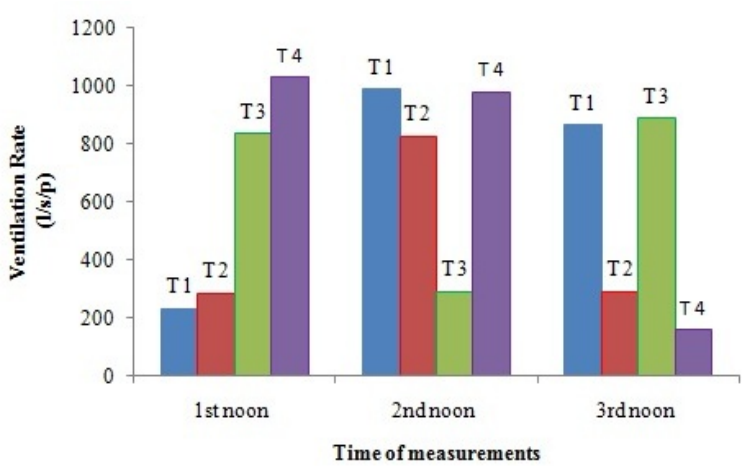

Figure 8. Noon ventilation rate 
Figure 7 for morning session, indicates the highest ventilation rate is $1233.83 \mathrm{l} / \mathrm{s} / \mathrm{p}$ in toilet 3 and for the lowest value is $154.23 \mathrm{l} / \mathrm{s} / \mathrm{p}$ at toilet 1 on the same $1^{\text {st }}$ day of measurement. In the afternoon, the highest value is 1028.19 $1 / \mathrm{s} / \mathrm{p}$ at toilet 4 on the $1^{\text {st }}$ day of measurement and the lowest is $157.66 \mathrm{l} / \mathrm{s} / \mathrm{p}$ at toilet 4 on the $3^{\text {rd }}$ day of measurement. These results indicated that few of toilets are experiencing ventilation rate that are lower than the standard requirement of CIBSE (2001)

\section{3 $\mathrm{SO}_{2}$ Concentration}

The $\mathrm{SO}_{2}$ concentrations in all the 4 toilets were measured for 10 minutes duration in the morning and at noon time in 3 consecutive days. The measured $\mathrm{SO}_{2}$ concentrations are as in figures 9 and 10 . The measured $\mathrm{SO}_{2}$ from all the toilets are compared to the TLV of $\mathrm{SO}_{2}$ exposure which is $0.4 \mathrm{ppm}$ (Protection, 2004; The National Advisory Committe for Acute Exposure Guideline Levels for Hazardous, 2008).

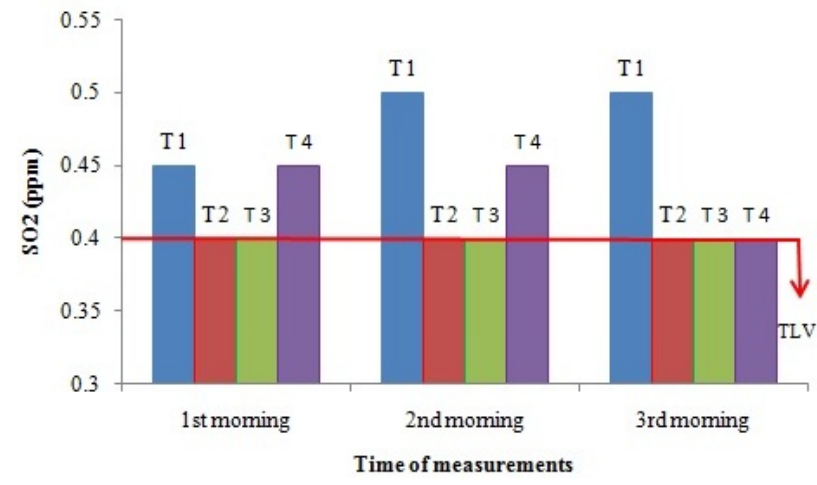

Figure 9. Measured morning SO2

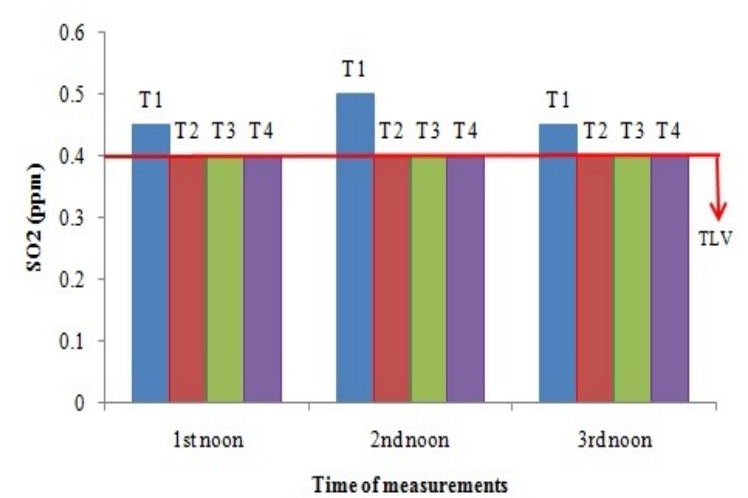

Figure 10. Measured noon SO2

Figure 9 for morning measurement, $\mathrm{SO}_{2}$ concentrations in toilet 1 and 4 exceeded the TLV of $\mathrm{SO}_{2}$ with the value recorded up to $0.5 \mathrm{ppm}$. However, for noon time, only toilet 1 experience $\mathrm{SO}_{2}$ concentrations exceeding the TLV up to $0.5 \mathrm{ppm}$. This situation is due to the inadequacy of air velocity/ventilation to dilute the indoor $\mathrm{SO}_{2}$ pollutant. Besides that, in toilet 1 there occupants who are smoking during the measurement period were conducted.

\section{Conclusion}

The IAQ study in 4 selected toilets was carried out by measuring humidity, temperature, air velocity and $\mathrm{SO}_{2}$ for assessing the conditions of the toilets that could trigger asthmatic symptom for those asthmatic people who are frequently used the toilets. The findings that can be drawn from this study are as follows:

1) It was found that $\mathrm{SO}_{2}$ concentration in toilet 1 exceeded the TLV of $\mathrm{SO}_{2}$ exposure for 10 minutes. This means that the toilet has the potential to trigger asthmatic symptom for those asthmatic people who frequently used this toilet.

2) Inadequate of air velocity/ventilation in toilet 1 for diluting indoor pollutant such as $\mathrm{SO}_{2}$ contributes to the increment of $\mathrm{SO}_{2}$ concentration. Additionally, indoor air humidity which was recorded indicates that this toilet is humid and it can affect to the growth of mold which also can trigger to asthmatic symptoms (Al-anzi \& Salman, 2011).

3) The behavior of toilet user such as smoking at toilet can affect to the increases of indoor air pollutants which again increase the potential of trigerring asthmatic symptoms

\section{Acknowledgements}

Thanks and gratitude to Ministry of Higher Education Malaysia and Research and Innovation Centre of Universiti Tun Hussein Onn Malaysia for funding this paper under Short Term Grant (STG) vote 1073 . 


\section{References}

Al-anzi, F. S., \& Salman, A. A. (2011). Correlation of Asthma Symptoms with Prevalence of Indoor $\mathrm{NO}_{2}$ Concentration in Kuwait. Journal of Environmental Protection, 2011(2), 186-193. http://dx.doi.org/10.4236/jep.2011.22021

Awbi, H. B. (1991). Ventilation of Buildings (Vol. 6, p. 309). London, UK: E \& FN SPON. http://dx.doi.org/10.1371/journal.pone.0022470

Balmes, J. R., Fine, J. M., \& Sheppard, D. (1987). Symptomatic bronchoconstriction after short-term inhalation of sulfur dioxide. Am. Rev. Respir. Dis, (136), 1117-1121.

Bousquet, J., Jeffery, P. K., Busse, W. W., Johnson, M., \& Vignola, A. M. (2000). Asthma, From Bronchoconstriction to Airways Inflammation and Remodeling. American Journal of Respiratory and Critical Care Medicine, 161, 1730-1745.

Brunekreef, B., \& Forsberg, B. (2005). Epidemiological evidence of effects of coarse airborne particles on health. The European Respiratory Journal: Official Journal of the European Society for Clinical Respiratory Physiology, 26(2), 309-18. http://dx.doi.org/10.1183/09031936.05.00001805

Chartered Institution of Building Services Engineers (CIBSE) Guide B2, "Heating, Ventilating, Air Conditioning, and Refrigetarion," 2001.

Donaldson, K., Gilmour, M. I., \& Macnee, W. (2000). Commentary Asthma and PM 10. Respiratory Research, 1, $12-15$.

Frontczak, M., \& Wargocki, P. (2011). Literature survey on how different factors influence human comfort in $\begin{array}{llll}\text { indoor environments. Building and } & \text { Environment, 46(4), }\end{array}$ http://dx.doi.org/10.1016/j.buildenv.2010.10.021

Guo, P. (2012). Survival Analysis of Victims of Sulfur Oxide Air Pollution Suffering from COPD or Asthma in Yokkaichi, Japan, in Relation to Predisposing Exposure. Journal of Environmental Protection, 3(29), 1251-1259. doi:10.4236/jep.2012.329142

Karakatsani, A., Analitis, A., Perifanou, D., Ayres, J. G., Harrison, R. M., Kotronarou, A., \& Katsouyanni, K. (2012). Particulate matter air pollution and respiratory symptoms in individuals having either asthma or chronic obstructive pulmonary disease: A European multicentre panel study. Environmental Health: A Global Access Science Source, 11(1), 75. http://dx.doi.org/10.1186/1476-069X-11-75

Koren, H. S. (1995). Associations between criteria air pollutants and asthma. Environmental Health Perspectives, 103Suppl(9), 235-42. Retrieved from http://www.pubmedcentral.nih.gov/ articlerender.fcgi? artid $=1518942 \&$ tool $=$ pmcentrez\&rendertype $=$ abstract

Lee, S. (1997). Comparison of Indoor and Outdoor Air Quality at Two Staff Quarters in Hongkong. Environmental International, 23(97), 791-797.

Luttinger, D., \& Wilson, L. (2003). A study of air pollutants and acute asthma exacerbations in urban areas: status report. Environmental Pollution, 123(3), 399-402. http://dx.doi.org/10.1016/S0269-7491(03)00025-3

Massey, D., Masih, J., Kulshrestha, A., Habil, M., \& Taneja, A. (2009). residential homes locations in central Indian region. Building and Environment, 44(10), 2037-2045. http://dx.doi.org/10.1016/j.buildenv.2009.02.010

Muhamad-darus, F., Zain-ahmed, A., \& Talib, M. (2011). Preliminary Assessment of Indoor Air Quality in Terrace Houses. Health and the Environmental Journal, 2(2), 8-14.

Murdoch, J. R., \& Lloyd, C. M. (2010). Chronic inflammation and asthma. Mutation Research, 690(1-2), 24-39. http://dx.doi.org/10.1016/j.mrfmmm.2009.09.005

Protection, N. E. (2004). Review of the Practicability of a 10 Minute Sulfur Dioxide Standard Issues Paper.

Restrepo, C. E. (2012). Asthma Hospital Admissions and Ambient Air Pollutant Concentrations in New York City. Journal of Environmental Protection, 3(29), 1102-1116. http://dx.doi.org/10.4236/jep.2012.329129

Sheppard, D., Wong, W. S., Uehara, C. F., Nadel, J. J., \& Boushry, H. A. (1980). Lower threshold and greater bronchomotor responsiveness of asthmatic subjects to sulfur dioxide. Am. Rev. Resp. Dis., 122, 873-878. http://dx.doi.org/10.1016/j.artmed.2004.01.013

The National Advisory Committe for Acute Exposure Guideline Levels for Hazardous. (2008). Sulfur Dioxide (CAS Reg . No . 7446-09-5 ) ( AEGLs ). 
Tseng, C. Y., Huang, Y. C., Su, S. Y., Huang, J. Y., Lai, C. H., Lung, C. C., \& Liaw, Y. P. (2012). Cell type specificity of female lung cancer associated with sulfur dioxide from air pollutants in Taiwan: an ecological study. BMC Public Health, 12(1), 4. http://dx.doi.org/10.1186/1471-2458-12-4

World Health Organization. (1987). Air Quality Guidelines for Europe. Copenhagen, Denmark.

Zhang, Y. (2005). Indoor Air Quality Engineering. Journal of Membrane Science (Vol. 240). USA: CRC Press LLC.

\section{Copyrights}

Copyright for this article is retained by the author(s), with first publication rights granted to the journal.

This is an open-access article distributed under the terms and conditions of the Creative Commons Attribution license (http://creativecommons.org/licenses/by/3.0/). 